\title{
Effect of regional topography and hydrology on the lacustrine isotopic record of Miocene paleoclimate in the Rocky Mountains
}

\author{
Carl N. Drummond, Bruce H. Wilkinson, Kyger C. Lohmann and Gerald R. Smith \\ Department of Geological Sciences, The University of Michigan, Ann Arbor, MI 48109-1063, USA \\ (Received May 4, 1992; revised and accepted October 23, 1992)
}

\begin{abstract}
Drummond, C.N., Wilkinson, B.H., Lohmann, K.C. and Smith, G.R., 1993. Effect of regional topography and hydrology on the lacustrine isotopic record of Miocene paleoclimate in the Rocky Mountains. Palaeogeogr., Palaeoclimatol., Palaeoecol., 101: $67-79$.

Oxygen isotopic compositions of upper Miocene $(9.2 \mathrm{~m} . \mathrm{y}$.) lacustrine limestone from northwestern Wyoming range from -21.5 to $-35.2 \%$ (PDB) and are the lightest yet reported for a non-marine carbonate sequence. These values require that lake water was greatly depleted in ${ }^{18} \mathrm{O}$ relative to modern meteoric precipitation and indicate that most inflow was sourced as meltwater from glaciers in the adjacent Gros Ventre range. Assessment of climatic factors influencing the isotopic composition of global meteoric water indicates either that nearly all of Miocene precipitation in the southern Rocky Mountains was derived from large lake systems in the Snake River Plain and northern Great Basin to the west, or that Gros Ventre catchment elevations were up to $2300 \mathrm{~m}$ higher than at present. Because erosion rates in modern alpine regions suggest that subaerial denudation could only account for up to $1200 \mathrm{~m}$ of post-Miocene elevation reduction, any additional lowering must reflect the influence of post-Laramide epeirogeny during Basin and Range extensional tectonism. Lacustrine isotopic data therefore provide boundary conditions on the timing and magnitude of changes in late Cenozoic paleoclimate, topography, hydrology, and tectonism in the western Wyoming portion of the Rocky Mountains.
\end{abstract}

\section{Introduction}

Nearly continuous sedimentation and rapid isotopic response to climate change makes large lakes nearly ideal settings for high-resolution studies of paleoclimate. Moreover, measurement of lacustrine carbonate stable isotopic ratios has become one of the standard methods of paleoclimatic research over the past two decades (e.g. Fritz et al., 1975; Kelts and Talbot, 1986; Kelts and Talbot, 1989; McKenzie, 1985; McKenzie and Eberli, 1987; Schoell, 1978; Stiller and Kaufman, 1985; Stuiver, 1970 and Suchecki et al., 1988; Talbot, 1990). However, one commonly overlooked factor that may

Correspondence to: C.N. Drummond, Department of Geological Sciences, The University of Michigan, Ann Arbor, MI 48109-1063, USA. significantly influence the isotopic composition of meteoric water and associated sediment is the elevation of drainage basins from which lake water is derived. Extremely-depleted $\delta^{18} \mathrm{O}$ compositions of lacustrine limestone in the Miocene Camp Davis Formation of northwestern Wyoming strongly implicate an important local control on lake water composition independent of regional climate, and serve to emphasize the influence of drainage basin elevation on the isotopic composition of meteoric water in various lacustrine settings.

\section{Sedimentology-stratigraphy}

The upper Miocene Camp Davis Formation consists of lake-margin lacustrine carbonate, syntectonic alluvial conglomerate, and bedded and disseminated volcanic ash (Davis and Wilkinson, 
1983). Sediments were deposited in a half-graben basin bound to the northeast by the Hoback fault which was active during Miocene Great Basin extensional tectonism (Davis and Wilkinson, 1983). The Camp Davis Formation crops out along $15 \mathrm{~km}$ of NW-trending exposures that parallel strike of the Hoback normal fault. This fault separated the Camp Davis lake basin and adjacent alluvial fans from the Gros Ventre Mountains immediately to the northeast (Fig. 1). The Gros Ventres are a Laramide mountain range that served as the source of both terrigenous sediment and meteoric runoff to surrounding fluvial systems and the lake basin (Davis and Wilkinson, 1983). Limestone lithofacies are similar to those found in many freshwater marl deposits (Murphy and Wilkinson, 1980; Treese and Wilkinson, 1982) and consist primarily of massive to root mottled micrites and intraclastic to pisolitic to oolitic grainstones. The dominance of these facies in all Camp Davis exposures, the ubiquitous presence of the green alga Chara, and the common occurrence of molds of freshwater gastropods and ostracodes, all strongly indicate that deposition took place in a fairly typical hard-water lake system, probably similar to those that now predominate throughout northern temperate regions. Equant to fibrous pore-filling calcite cement in oolitic, pisolitic, and intraclastic units is a significant component of most grainstone samples.

Based upon faunal evidence, Dorr et al. (1977) estimated the Camp Davis Formation to be late Miocene to early Pliocene. A layer of volcanic ash that directly overlies the lacustrine carbonate sequence has been chemically correlated with ash in the nearby Teewinot Formation (Ritchie, 1981; Love, 1986). Evernden et al. (1964), using $\mathrm{K}-\mathrm{Ar}$ techniques, dated volcanic ash of the Teewinot at 9.2 m.y.; thereby constraining a minimum age of the Camp Davis as Tortonian (late Miocene).

\section{Isotopic chemistry}

Because molluscan macro-fossils within Camp Davis limestones are only preserved as molds of now-dissolved aragonite, isotopic data exclusively reflect the compositions of calcitic components. Virtually all of these exhibit similar carbon and oxygen isotopic signatures. Oxygen isotopic compositions of massive micrite, intraclastic micrite, and pisolitic algal micrite range from -22.1 to $-31.1 \%$ (PDB) while syn-sedimentary cements range from -21.5 to $-35.2 \%$ (Fig. 2, Table 1). Moreover, coupled petrographic and isotopic

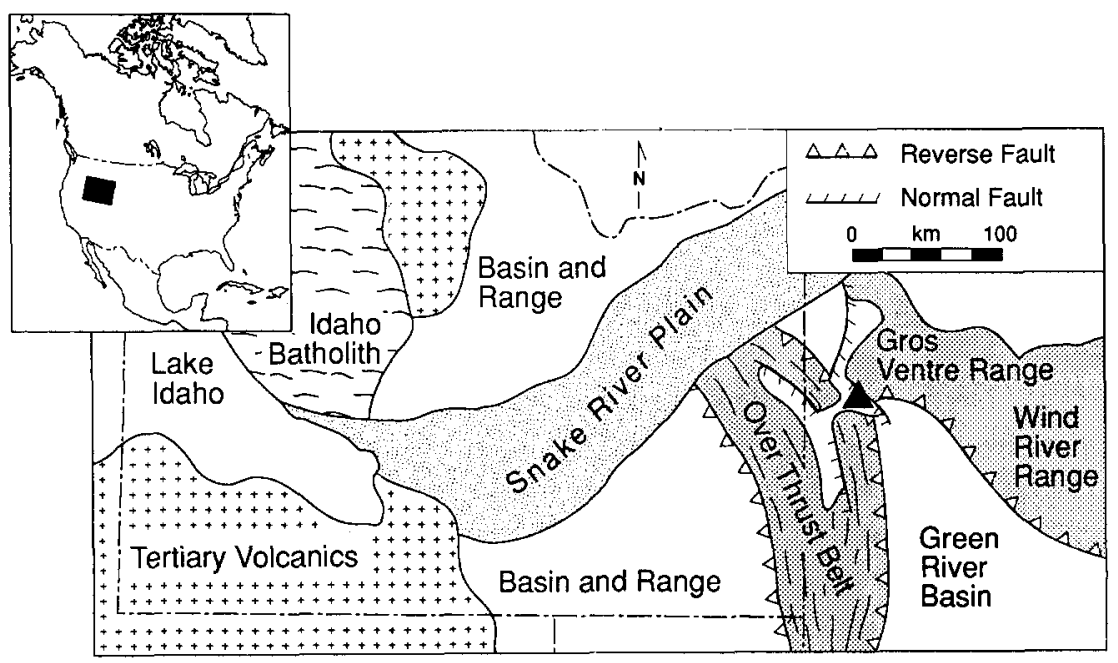

Fig. 1. Late Miocene geologic/tectonic setting of western Wyoming and southern Idaho as shown by the regional map, located in the western portion of North America. Note the location of Lake Camp Davis (extending from the western-southwestern margin of the Gros Ventre range and along the Palisades graben of the Wyoming-Idaho Overthrust Belt) and Lake Idaho (along the western portion of the Snake River Plain). Carbonates sampled during this study were collected from exposures of the Camp Davis formation immediately downthrown along the Hoback normal fault (filled triangle). 
TABLE 1

Lithology, isotopic composition, and equilibrium precipitation temperature/fluid composition of Miocene Camp Davis carbonates

\begin{tabular}{|c|c|c|c|c|c|c|}
\hline LITH & $\begin{array}{l}\delta^{13} \mathrm{C} \\
(\mathrm{PDB})\end{array}$ & $\begin{array}{l}\delta^{18} \mathrm{O} \\
(\mathrm{PDB})\end{array}$ & $\begin{array}{l}\delta^{18} \mathrm{O} \\
\text { (SMOW) }\end{array}$ & $\begin{array}{l}\text { TMP EQL } \\
\text { MOD PPT } \\
\left({ }^{\circ} \mathrm{C}\right)\end{array}$ & $\begin{array}{l}30^{\circ} \mathrm{C} \text { EQL } \\
\text { WAT COMP } \\
\text { (SMOW) }\end{array}$ & $\begin{array}{l}20^{\circ} \mathrm{C} \mathrm{EQL} \\
\text { WAT COMP } \\
\text { (SMOW) }\end{array}$ \\
\hline Al CLS & -8.85 & -27.79 & 2.27 & 82.86 & -25.09 & -27.19 \\
\hline A2 CLS & -7.44 & -31.28 & -1.34 & 110.65 & -28.70 & -30.80 \\
\hline A3 CLS & -9.24 & -29.13 & 0.88 & 93.14 & -26.48 & -28.58 \\
\hline $\mathrm{B} 1 \mathrm{BCC}$ & 0.74 & -25.83 & 4.28 & 68.80 & -23.08 & -25.18 \\
\hline $\mathrm{B} 2 \mathrm{BCC}$ & 1.29 & -29.69 & 0.30 & 97.60 & -27.06 & -29.16 \\
\hline $\mathrm{B} 3 \mathrm{BCC}$ & -0.49 & -28.49 & 1.54 & 88.20 & -25.82 & -27.92 \\
\hline $\mathrm{B} 4 \mathrm{BCC}$ & 0.32 & -29.46 & 0.54 & 95.77 & -26.82 & -28.92 \\
\hline $\mathrm{CI} \mathrm{BCC}$ & -0.05 & -28.36 & 1.67 & 87.19 & -25.69 & -27.79 \\
\hline D1 BCC & 2.93 & -21.50 & 8.74 & 41.50 & -18.62 & -20.71 \\
\hline C2 BLD & 1.45 & -35.19 & -5.36 & 145.72 & -32.72 & -34.82 \\
\hline D2 BLD & 0.00 & -23.92 & 6.25 & 56.14 & -21.11 & -23.21 \\
\hline D3 BLD & 3.47 & -23.79 & 6.38 & 55.31 & -20.98 & -23.08 \\
\hline D4 BLD & 0.86 & -22.93 & 7.28 & 49.91 & -20.08 & -22.18 \\
\hline A4 BRS & 0.45 & -24.83 & 5.31 & 62.02 & -22.05 & -24.15 \\
\hline B5 BRS & 6.03 & -23.12 & 7.08 & 51.08 & -20.28 & -22.38 \\
\hline B6 BRS & -0.24 & -33.31 & -3.43 & 128.36 & -30.79 & -32.89 \\
\hline C3 BRS & 4.60 & -29.91 & 0.07 & 99.36 & -27.29 & -29.39 \\
\hline C4 BRS & 0.87 & -29.31 & 0.70 & 94.52 & -26.66 & -28.76 \\
\hline C5 BRS & 2.67 & -27.68 & 2.37 & 82.10 & -24.99 & -27.09 \\
\hline C6 BRS & 3.12 & -30.66 & -0.70 & 105.44 & -28.06 & -30.15 \\
\hline B7 LAM & 1.02 & -28.30 & 1.73 & 86.74 & -25.63 & -27.73 \\
\hline B8 LAM & 0.18 & -29.55 & 0.44 & 96.49 & -26.92 & -29.02 \\
\hline D5 MBM & -0.62 & -22.05 & 8.17 & 44.70 & -19.19 & -21.29 \\
\hline A5 TMI & -0.91 & -28.64 & 1.38 & 89.36 & -25.98 & -28.08 \\
\hline C7 TMI & 2.09 & -31.10 & -1.15 & 109.14 & -28.51 & -30.61 \\
\hline C8 TMI & 2.32 & -24.57 & 5.58 & 60.31 & -21.78 & -23.88 \\
\hline D6 TMI & -0.57 & -24.09 & 6.07 & 57.21 & -21.29 & -23.39 \\
\hline Average & 1.31 & -27.35 & 2.72 & 81.37 & -24.64 & -26.74 \\
\hline
\end{tabular}

LITH = Component lithology $(\mathrm{BCC}=$ banded clear/columnar spar; $\mathrm{BLD}=$ bladed spar; $\mathbf{B R S}=$ equant brown spar; $\mathrm{CLS}=$ clear equant spar; $\mathrm{LAM}=$ laminated algal micrite; $\mathrm{MBM}=$ massive brown micrite; $\mathrm{TMI}=\tan$ micrite intraclast). TMP EQL MOD PPT = Equilibration temperature with modern meteoric water ( $-16.5 \%$ SMOW; Epstein et al., 1953). EQL WAT COMP = Equilibrium water composition at 30 and $20^{\circ} \mathrm{C}$ (O'Neil et al., 1964). Mean values exclusive of clear equant spar.

studies indicate that cement and micritic components have similar $\delta^{18} \mathrm{O}$ compositions within the same hand sample. Carbon isotopic compositions of all components range from 6.1 to $-9.2 \%$ (PDB), but the three lightest of these are clear calcite spar. Because this is the youngest (porelining) cement phase, the $\delta^{13} \mathrm{C}$ range of earlier phases is in fact much narrower 6.1 to $-0.9 \%$. Isotopic similarity between micrite and cement, and textural/mineralogical (low-magnesian calcite) similarity between Camp Davis cement and synsedimentary cement reported from other non- marine settings (Irion and Muller, 1968; Riding, 1979; Boyer, 1981) suggest that both micritic and cement components precipitated directly from lake water during carbonate accumulation (Davis and Wilkinson, 1983).

In order to place these values in a somewhat broader context, isotopic data on 670 modern and ancient lacustrine carbonates from a variety of geographic and tectonic settings were tabulated from the literature (Fig. 3). Among the dozen or so ancient and modern lacustrine settings represented by this tabulation, few even approach the most 


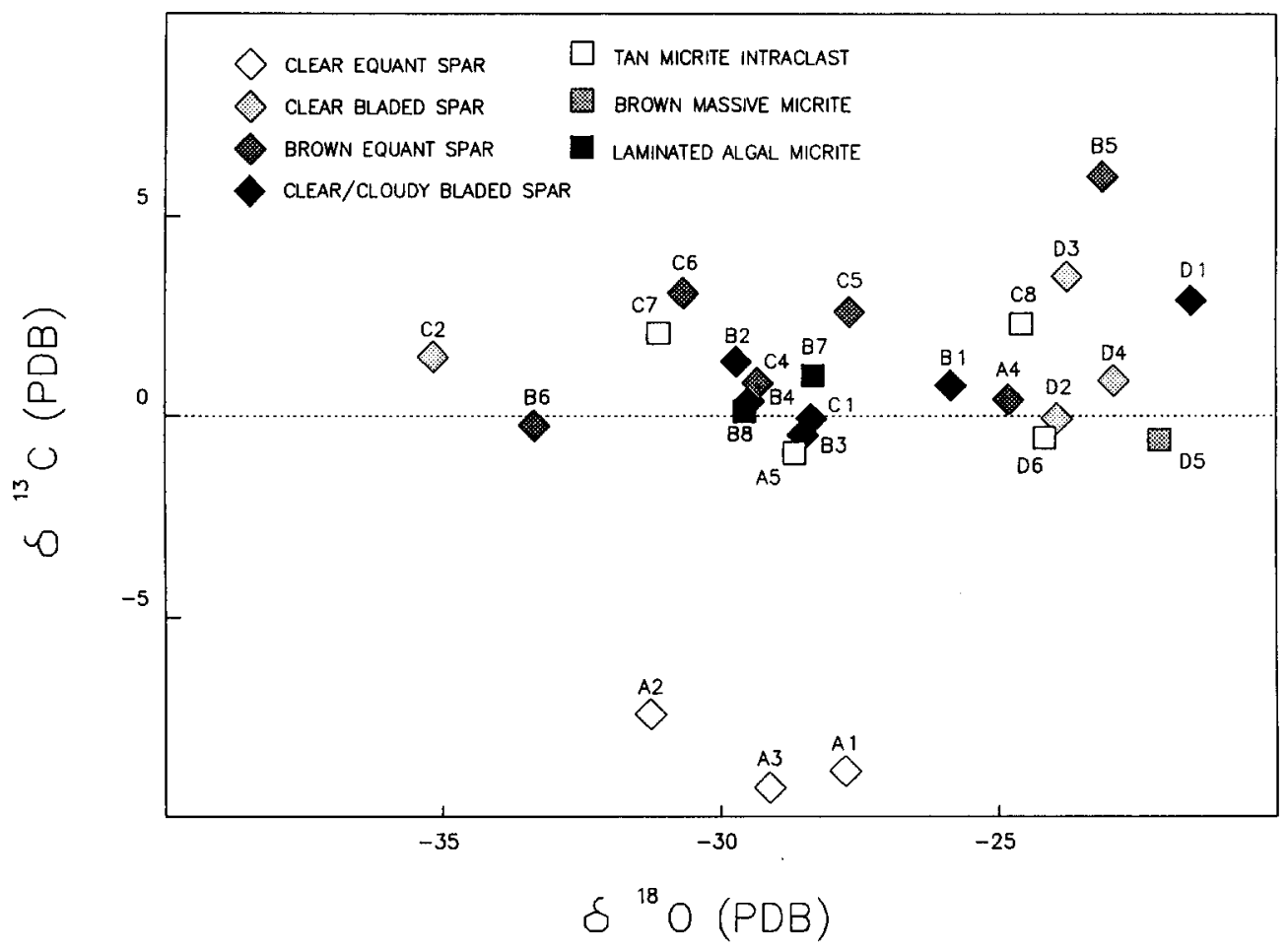

Fig. 2. Carbon and oxygen isotopic compositions of micrite and syn-sedimentary cement from lacustrine carbonates of the upper Miocene Camp Davis Formation. Micrite $\delta^{18} \mathrm{O}$ values (squares) range from -22.1 to $-31.1 \%$ (PDB) with a mean of $-26.9 \%$. Synsedimentary cement (diamonds) $\delta^{18} \mathrm{O}$ values range from $-21.5 \%$ to $-35.2 \%$ with a mean of $-27.8 \%$. With the exception of clear equant spar (latest cement), micrite and cement span a similar range of $\delta^{13} \mathrm{C}$ compositions $(-0.9-6.0 \%$; PDB).

enriched Camp Davis composition (Fig. 3). In fact, the only reported occurrences of non-marine carbonate as light as Camp Davis limestones are meteoric calcite as cement and concretions in Cretaceous and Quaternary sandstones from Australia and Antarctica (Gregory et al., 1989; Schmidt and Friedman, 1974).

Given the present climate, elevation, and geographic position of northwestern Wyoming, we might first ask if Camp Davis limestones are more ${ }^{18} \mathrm{O}$-depleted than would be expected under present conditions. Use of spring snow-melt $\delta^{18} \mathrm{O}$ values $(-16.5 \%$ SMOW) as a proxy of average western Wyoming meteoric water, and the carbonate-water paleotemperature relation of Epstein et al. (1953), calculated temperatures of carbonate precipitation range from 40 to $145^{\circ} \mathrm{C}$ (Table 1). Such temperatures are clearly too high for the formation of a relatively fossil-rich lacustrine carbonate. Moreover, assuming a geothermal gradient of some $25^{\circ} \mathrm{C} / \mathrm{km}$ and infinitely high water/rock ratios during alteration, more than $2.5 \mathrm{~km}$ of postMiocene sediment would be required to attain these temperatures in a deep diagenetic setting. Given that present outcrops presently occur at an elevation of about $2.0 \mathrm{~km}$, such burial would result in a local mean elevation, within this basin of deposition, higher than any point presently in the state of Wyoming. On the basis of these considerations, it seems apparent that the isotopic composition of Camp Davis limestones must therefore record carbonate deposition in Upper Miocene lake water that was significantly more depleted than modern meteoric precipitation.

Using the calcite-water isotopic partitioning relation of O'Neil et al. (1964) and a mean isotopic value of Camp Davis calcite, and assuming that temperatures of carbonate precipitation in Lake Camp Davis were similar to temperatures of maximum calcium draw-down in modern temperateregion marl lake systems (Wetzel, 1975), Camp Davis lake water had a composition of $-26.7 \%$ 


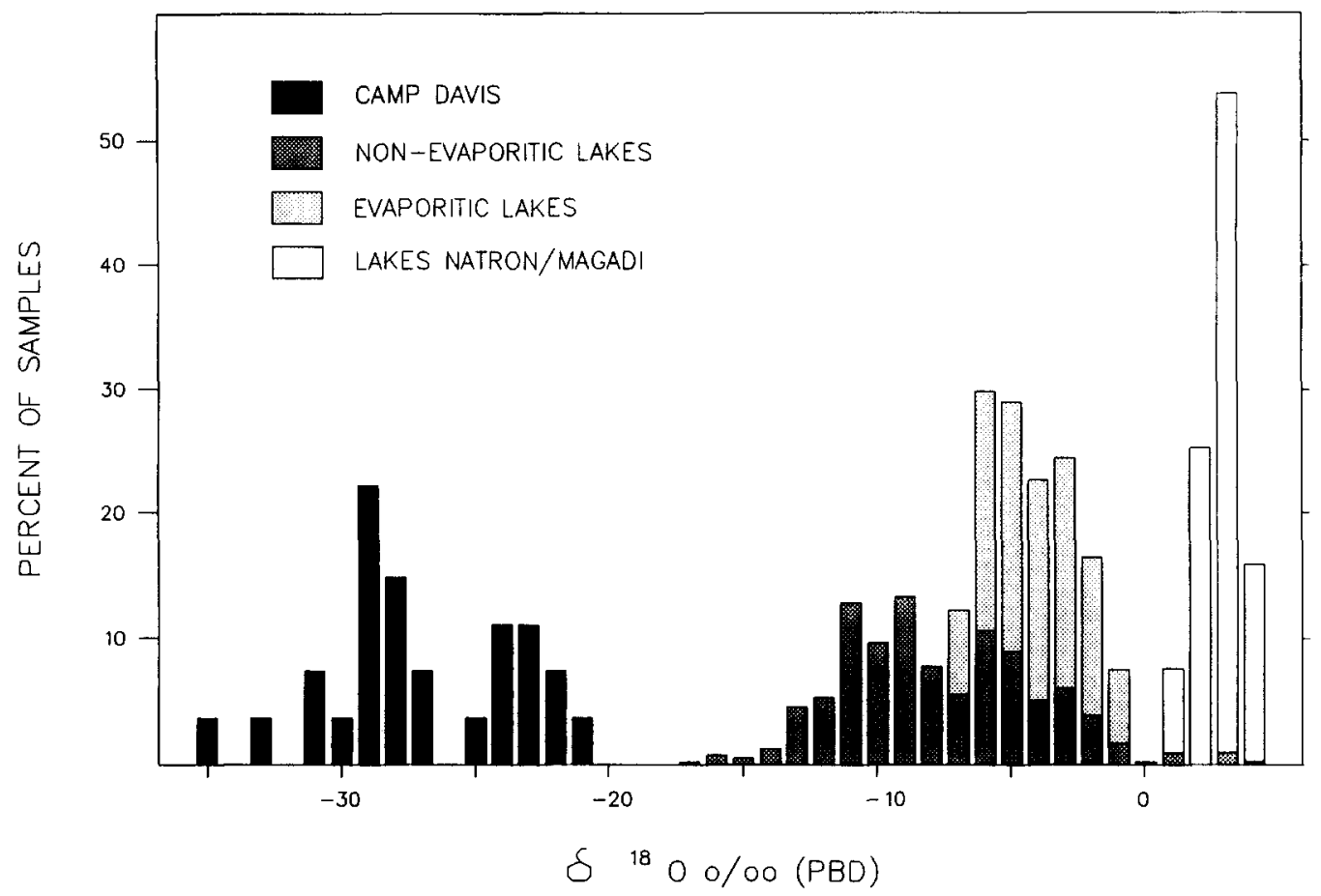

Fig. 3. Oxygen isotopic compositions of Camp Davis limestone components compared to 670 isotopic measurements of modern and ancient lacustrine carbonates from a variety of geographic and tectonic settings (Abell and Williams, 1989; Bein, 1986; Bellanca et al., 1989; Eicher et al., 1981; Eicher and Siegenthaler, 1976; Fritz and Poplawski, 1974; Hillaire-Marcel and Casanova, 1987; Schwarcz and Eyles, 1992; Stuiver, 1970; Suchecki et al., 1988). Note that Camp Davis values comprise the most depleted lake carbonates within this data set.

(SMOW) if carbonate precipitation occurred at $20^{\circ} \mathrm{C}$ and $-24.6 \%$ if at $30^{\circ} \mathrm{C}$ (Table 1 ). Moreover, these are relatively conservative estimates of lake water $\delta^{18} \mathrm{O}$ in that even lower temperatures would lead to estimated water compositions water even more depleted than $-26.7 \%$.

Comparison of this range of Miocene water compositions with latitudinally-equivalent meteoric water compositions from International Atomic Energy Agency-World Meteorologic Organization (IAEA-WMO) network stations (1969-1990) shows that the inferred composition of Camp Davis meteoric water falls well below the range of mean annual compositions of IAEA-WMO stations, and at the edge of the compositional range defined by monthly minimum compositions for these same stations (Fig. 4).

Why then, was Camp Davis lake water extremely depleted in ${ }^{18} \mathrm{O}$ compared to modern and ancient lacustrine systems and relative to modern meteoric precipitation? The answer to this query is not only important in understanding late Miocene paleoclimate, but also because the influence of elevation on the isotopic composition of meteoric precipitation can provide independent data from which to evaluate the tectonic and erosion history of this portion of the southern Rocky Mountains.

\section{Controls on meteoric water composition}

In meteoric systems, mass fractionation of ${ }^{18} \mathrm{O}$ between liquid and vapor operates at various scales, ranging from global variation related to latitude (Craig and Gordon, 1965), to regional climatic effects related to seasonal and annual temperature (Dansgaard, 1964), to local effects related to elevation (Smith et al., 1979). Within this spectrum, the primary mechanisms for isotopic change are temperature-dependent liquid/vapor fractionation, and the progressive reduction of residual water vapor mass with distance of vapor transport. Because Rayleigh fractionation and 


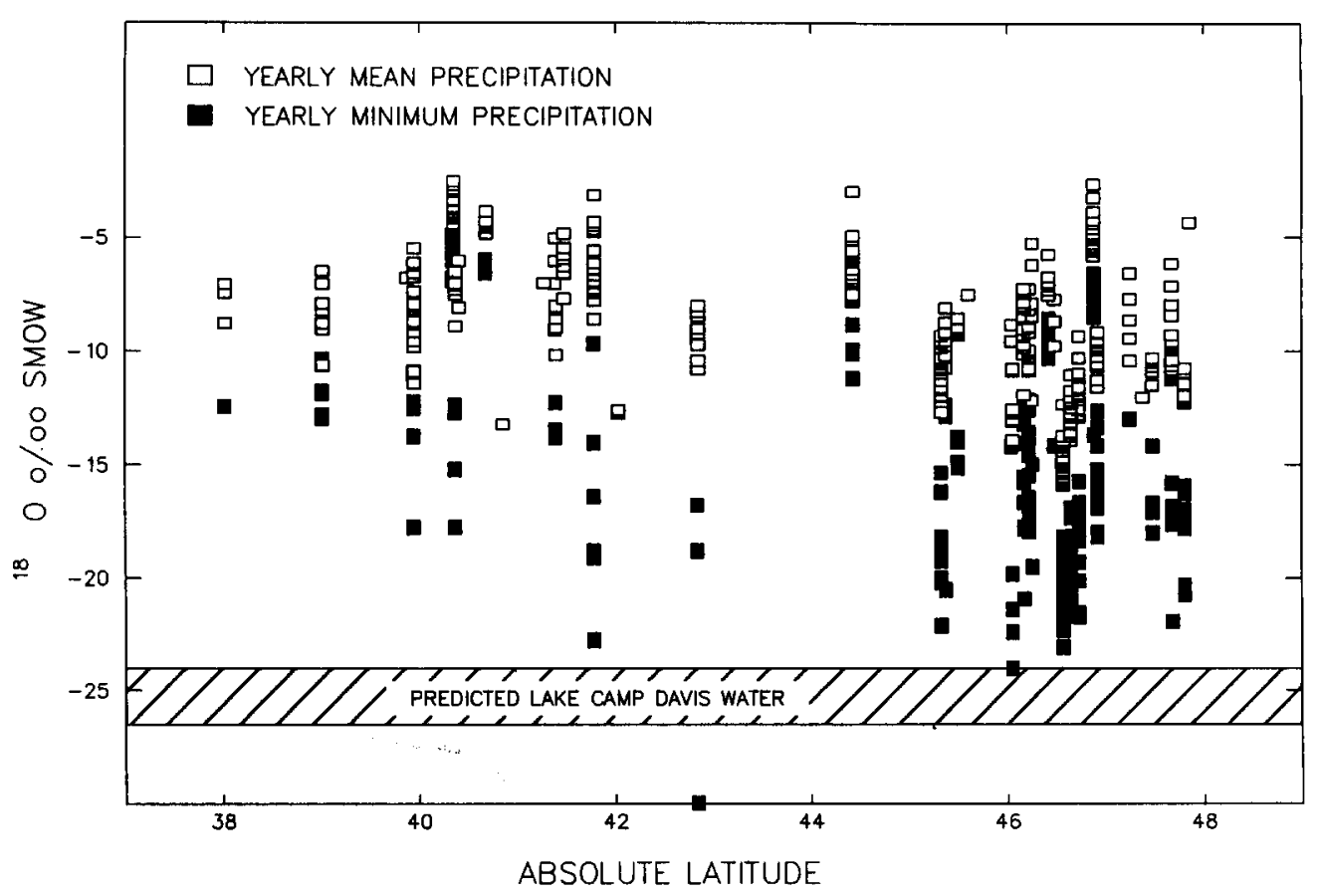

Fig. 4. Mean annual (open squares) and monthly minimum (solid squares) meteoric water isotopic compositions (weighted by amount of precipitation) from International Atomic Energy Agency-World Meteorological Organization (IAEA-WMO) (1969-1990) network stations within the latitude band of $38-48^{\circ}$. Note that predicted Miocene meteoric water values (at a paleolatitude of $43^{\circ}$ ) are significantly depleted relative to modern mean annual values and only fall at the lightest end of the range of monthly minimum values of global precipitation.

water loss during rainout is far more important than any increase in the value of the liquid-vapor isotopic fractionation factor with air mass cooling, decreasing temperature leads to extreme depletion of ${ }^{18} \mathrm{O}$ in the condensate. In the following we evaluate the potential controls of latitude, mean annual air temperature, and elevation on the isotopic composition of late Miocene meteoric water.

\section{Latitude effect}

Latitudinal control on the isotopic composition of meteoric water has long been known to be a direct reflection of poleward temperature gradient (Craig and Gordon, 1965; IAEA-WMO, 1969-1990). The importance of the latitude effect on the isotopic composition of Camp Davis Formation limestone can be evaluated from paleogeographic reconstructions based on paleomagnetic data from the North American craton. These show that Wyoming has shifted only slightly from its late
Miocene position (Van der Voo, 1989). The small magnitude of this shift precludes the possibility that depletion of Camp Davis lake water reflects any significant change in latitude over the past 9.2 m.y.

\section{Climatic control on mean annual air temperature}

An estimate of late Miocene temperature within the catchment basin of the Camp Davis lake can be derived from empirical relations between the composition of modern precipitation and air temperature (Dansgaard, 1964); these predict a late Miocene mean annual temperature in northwestern Wyoming between -16 and $-23^{\circ} \mathrm{C}$, some $20-25^{\circ} \mathrm{C}$ cooler than at present. If correct, this calculated change in temperature is certainly far too extreme given present understanding of the paleoflora of the region. Paleobotanical assessments of Tertiary paleoclimate in northwestern Wyoming and eastern Idaho have resulted in late Miocene 
temperature estimate that are similar or somewhat warmer than at present (Hildebrand and Newman, 1985; Axelrod, 1964). Leopold and MacGinitie (1972), for example, concluded that an Eocene subtropical flora was replaced by a more modern Rocky Mountain flora during the Miocene and Pliocene, and that late Miocene regional temperatures were no cooler than at present. Given these constraints, it follows that isotopic compositions of late Miocene meteoric water were not controlled by climatically-induced cooler temperature. Therefore, we conclude that localized influences such as higher catchment elevation must have been the driving mechanism for lighter meteoric water in northwestern Wyoming during the late Miocene.

\section{Elevation effect}

Elevation versus $\delta \mathrm{D}$ data from Smith et al. (1979) and elevation versus $\delta^{18} \mathrm{O}$ data from the IAEA-WMO network (1969-1990) were used to evaluate the influence of catchment basin elevations within the Gros Ventre range on the isotopic composition of local meteoric water. Meteoric water $\delta^{18} \mathrm{O}$ data from IAEA-WMO stations between 38 and $48^{\circ} \mathrm{N}$ latitude $\left( \pm 5^{\circ}\right.$ of lake Camp Davis late Miocene paleolatitude) define a elevation versus composition trend with slope of $-4.2 \% / \mathrm{km}$ and an intercept of $-7.0 \%$ (Fig. 5). This trend reflects isotopic response to decreasing water vapor mass with elevation, while the

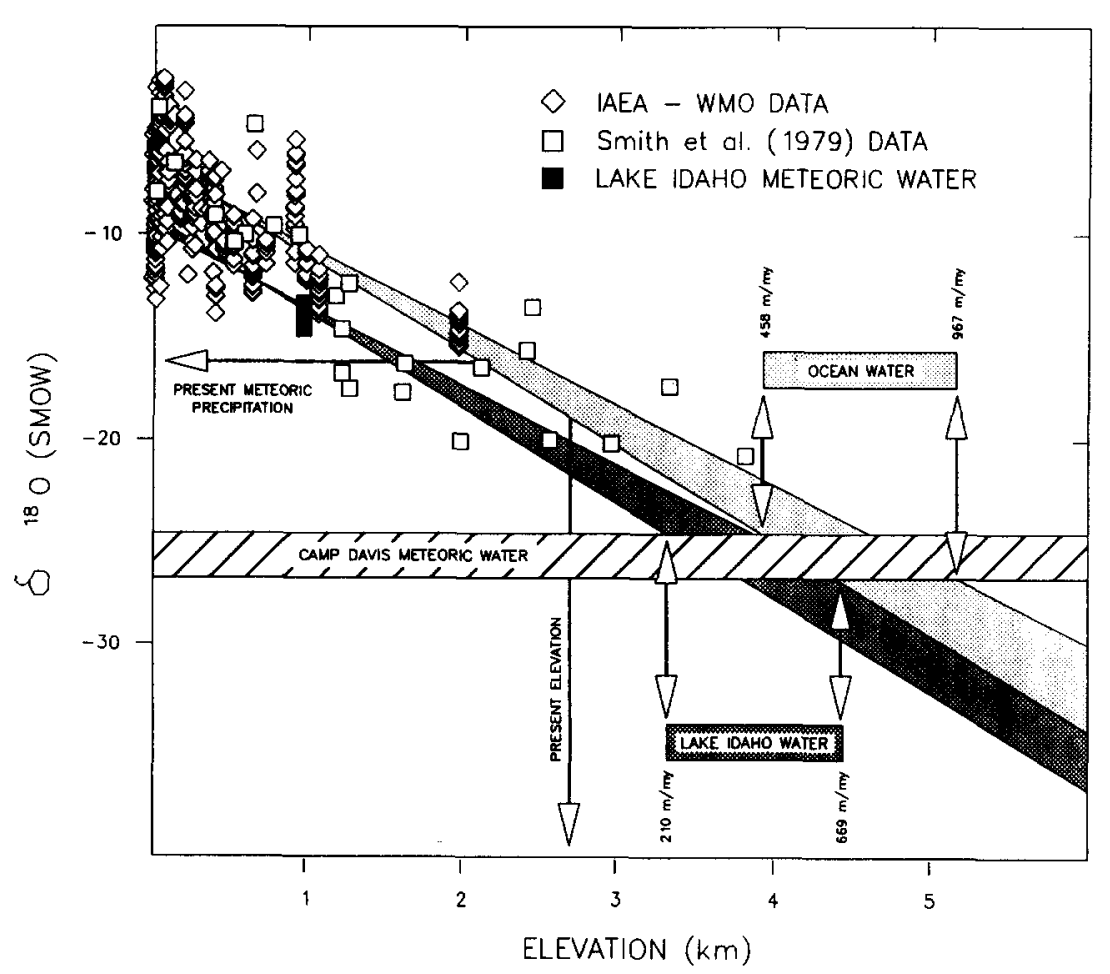

Fig. 5. Mean annual isotopic composition versus elevation for sea water-derived meteoric precipitation from IAEA-WMO network stations (1969-1990) within the latitude band of $38-48^{\circ}$ (open diamonds), from data in Smith et al. (1979) as filled squares, and as inferred from the isotopic composition of unaltered molluscan aragonite in shoreface sands of the Miocene Lake Idaho system (filled rectangle). Regression through either set of precipitation data yields a trend with slope of $-4.2 \% / \mathrm{km}$ and a sea level intercept of $-7 \%$ SMOW. Projection of $95 \%$ confidence limits around this trend (lightly stippled) through the inferred composition of Camp Davis precipitation (horizontal field) delimits mean catchment elevation $(3.9-5.1 \mathrm{~km}$ ) if all meteoric vapor were derived from oceanic sources (ocean water). Projection of these confidence limits through the inferred Lake Idaho water composition (medium stippled) delimits mean catchment elevation $(3.3-4.4 \mathrm{~km}$ ) if all meteoric vapor were derived form western regional lakes (lake Idaho water). Values at elevation limits reflect rates of lowering via subaerial erosion and/or tectonic subsidence necessary to reach the present mean elevation of Gros Ventre catchments over the past 9.2 m.y. 
intercept value is that of mean annual composition of precipitation at sea level within the latitude band. On the basis of this trend, and inferred late Miocene meteoric water compositions between -24.6 and $-26.7 \%$ (SMOW), mean catchment elevations in the Gros Ventre range are calculated to have been between 3.9 and $5.1 \mathrm{~km}$ above sea level, and imply that waters within paleo-Lake Camp Davis must have been glacially-sourced. Because the present mean height of the Gros Ventre Mountains is $2.8 \mathrm{~km}$, it follows that if elevation of Gros Ventre drainage basins was the dominant factor controlling ${ }^{18} \mathrm{O}$ depletion in Camp Davis water, the Gros Ventre Mountains have been reduced in height by $1.1-2.3 \mathrm{~km}$ since the late Miocene.

\section{Effect of meteoric water recycling}

Use of such elevation/composition relations also implies that sea water was the only vapor source from which meteoric water was derived. However, continental precipitation flux is nearly three times that of riverine discharge (Baumgartner and Reichel, 1975), and therefore requires significant cycling of meteoric precipitation through continental reservoirs. While at a global scale evapotraspiration is the principle pathway of surface water back to the atmosphere, large lakes can provide a significant portion of surface flux at a local and regional scale. During the late Miocene numerous large lakes which occupied basins between the Camp Davis area and the Pacific coast (Cole and Armentrout, 1979) potentially served as significant sources of recycled meteoric water for the region. Lake Idaho, for example, a large $\left(>1000 \mathrm{~km}^{2}\right)$ lake system coeval with the Camp Davis lake, lay immediately to the west within what is now the Snake River Plain (Straccia et al., 1990; Swrydczuk et al., 1979) at an elevation of approximately $1 \mathrm{~km}$. Given the size, westerly position, and potential evaporation surface these windward lake systems afforded, it is possible that a significant portion of meteoric precipitation falling on the Gros Ventre range was multiply fractionated via continental recycling (Fig. 1).

Unaltered molluscan shells from shoreface sands within the Lake Idaho system yield a $\delta^{18} \mathrm{O}$ value of
- 16\% (PDB), a value from which Lake Idaho water compositions of -15 to $-13 \%$ (SMOW) (depending on assumed precipitation temperatures of 20 and $30^{\circ} \mathrm{C}$, respectively) are derived. By projecting the $-4.2 \% / \mathrm{km}$ composition/elevation trend derived from the IAEA-WMO (1969-1990) and Smith et al. (1979) data through this estimated composition of Lake Idaho water, paleoelevation of the Gros Ventre Mountains can be derived when assuming that this lake was the only source of water vapor for late Miocene meteoric precipitation (Fig. 5). Such an approach yields mean catchment paleoelevations ranging from 3.3 to $4.4 \mathrm{~km}$, indicating that the mountains were lowered some $0.5-1.6 \mathrm{~km}$ since the late Miocene.

The importance of these calculations is that two end-member estimates for paleoelevation of the Gros Ventre Mountains can be developed: (1) if all meteoric vapor was derived from global oceans, mean late Miocene elevation of these mountains was between 3.9 and $5.1 \mathrm{~km}$ some $1.1-2.3 \mathrm{~km}$ higher than at present; (2) if all water vapor was derived via evaporation from Lake Idaho, the mountains were some $3.3-4.4 \mathrm{~km}$ in height and have been lowered some $0.5-1.6 \mathrm{~km}$ since that time. The difference between these two scenarios is significant in that each implicates very different rates of erosion over the past $9.2 \mathrm{~m} . \mathrm{y}$., and it is this difference, in conjunction with data on denudation rates from analogous mountainous regions, that allows for an evaluation of the importance of each scenario.

\section{Elevation reduction via erosion}

Using reasonable densities for crustal $\left(2.5 \mathrm{~g} / \mathrm{cm}^{3}\right)$ and sub-crustal rocks $\left(3.4 \mathrm{~g} / \mathrm{cm}^{3}\right)$ of the region (Shuster and Steidtmann, 1988; Smithson et al., 1978), the first scenario (1.1-2.3 km erosion) corresponds to isostatically corrected total crustal thinning of $4.2-8.9 \mathrm{~km}$ and to denudation rates ranging from 460 to $970 \mathrm{~m} / \mathrm{m}$.y. In contrast, the second scenario $(0.5-1.6 \mathrm{~km}$ erosion) corresponds to a total crustal thinning of $1.9-6.0 \mathrm{~km}$ and to denudation rates ranging from 200 to $670 \mathrm{~m} / \mathrm{m}$.y. For comparison, denudation rates from mountainous regions have been estimated at $100 \mathrm{~m} / \mathrm{m} . \mathrm{y}$. (Menard et al., 1965), 120-210 m/m.y. (Gilluly, 
1949; Menard, 1961), and 400-500 m/m.y. (Clarke and Jager, 1969). If post-Miocene erosion were the only process of elevation reduction in the Gros Ventre range, the hypothesis that most meteoric precipitation was derived from ocean water must be rejected because erosion rates of $460-970$ $\mathrm{m} / \mathrm{m}$.y. are excessive. Similarly, because reported mountainous denudation rates are generally similar to those inferred when assuming a significant input of meteoric water from Lake Idaho (200-670 m/m.y.) depleted Camp Davis carbonate compositions might reflect large-scale cycling of meteoric water through major lake systems to the west of lake Camp Davis. However, this scenario cannot be completely correct, in that some significant amount of water vapor supplied to the Gros Ventre range likely originated from oceanic sources without experiencing continental recycling and ${ }^{18} \mathrm{O}$ depletion.

Postulation of oceanic vapor sources alone leads to untenable rates of erosion, while acceptance of maximum erosion rates as reported from mountainous regions, results in relying on western lakes as the only important source of water vapor for meteoric precipitation. On the basis of these constraints, we conclude that some amount of postMiocene lowering must also reflect tectonic subsidence, probably in response to crustal thinning during Great Basin extensional tectonism.

\section{Elevation reduction via epirogenic subsidence}

If erosion in the Gros Ventre range since deposition of the Camp Davis Formation (9.2 m.y.) proceeded at the maximum rate reported from modern alpine regions (about $500 \mathrm{~m} / \mathrm{m}$.y.; Clarke and Jager, 1969), mean catchment elevations could have been no higher than about $4.0 \mathrm{~km}$, some 1200 $\mathrm{m}$ higher than at present. Any Miocene elevation estimate in excess of this value requires some amount of post-Miocene tectonic lowering (in addition to erosion) to account for the net decrease in elevation indicated by carbonate isotopic data (Fig. 6). In this context, maximum rates of tectonic movement in alpine regions are on the order of 120 $\mathrm{m} / \mathrm{m}$.y. (England and Molnar, 1990), a value equivalent to no more than $1.1 \mathrm{~km}$ of tectonic subsidence since deposition of the Camp Davis formation.
Although several workers (Couples and Stearns, 1978; Erslev, 1986) have emphasized the importance of post-Laramide subsidence along the southern Rocky Mountains, the late Cenozoic tectonic history of the region remains a matter of some debate (Steidtmann and Middleton, 1991; Steidtmann et al., 1989; Evanoff, 1990; Gregory and Chase, 1992). However, Barnosky and Labar (1989) have documented increased rates of subsidence in northwest Wyoming after the midMiocene.

\section{Post-Miocene lowering of the Rocky Mountains}

Determining the relative importance of erosional versus tectonic processes in lowering the Gros Ventre Mountains depends upon adequate knowledge of the height of this range in Miocene time and on the amount of elevation reduction that occurs during crustal thinning via erosion and extension. Although unique values for these rates can not be quantitatively determined from available data, allowable ranges can be estimated from data on: (1) the density of crustal and sub-crustal rocks; (2) maximum rates of erosion in analogous modern alpine regions; (3) maximum rates of epeirogenic movement determined in areas of active tectonism, and (4) estimated heights of meteoric catchments which are dependent on the relative amount of meteoric water vapor derived from global oceans and regional lakes. If, for example, post-Miocene lowering of the Gros Ventre Mountains only reflected surficial erosion, at least $75 \%$ of atmospheric water vapor delivered to Lake Camp Davis must have been sourced from lake Idaho (Fig. 6).

Employing such relations, it is apparent that either erosion alone, or subsidence alone, or some combination of erosion plus subsidence are sufficient to account for differences between Miocene and present isotopic compositions of meteoric precipitation in this region if most meteoric water vapor were derived from large coeval lakes in the western Snake River Plain (Fig. 7). With a greater contribution of ocean-derived vapor to local precipitation, first subsidence alone (about $8 \%$ oceanic vapor) and then erosion alone (about 25\% oceanic vapor) are insufficient to account for the 


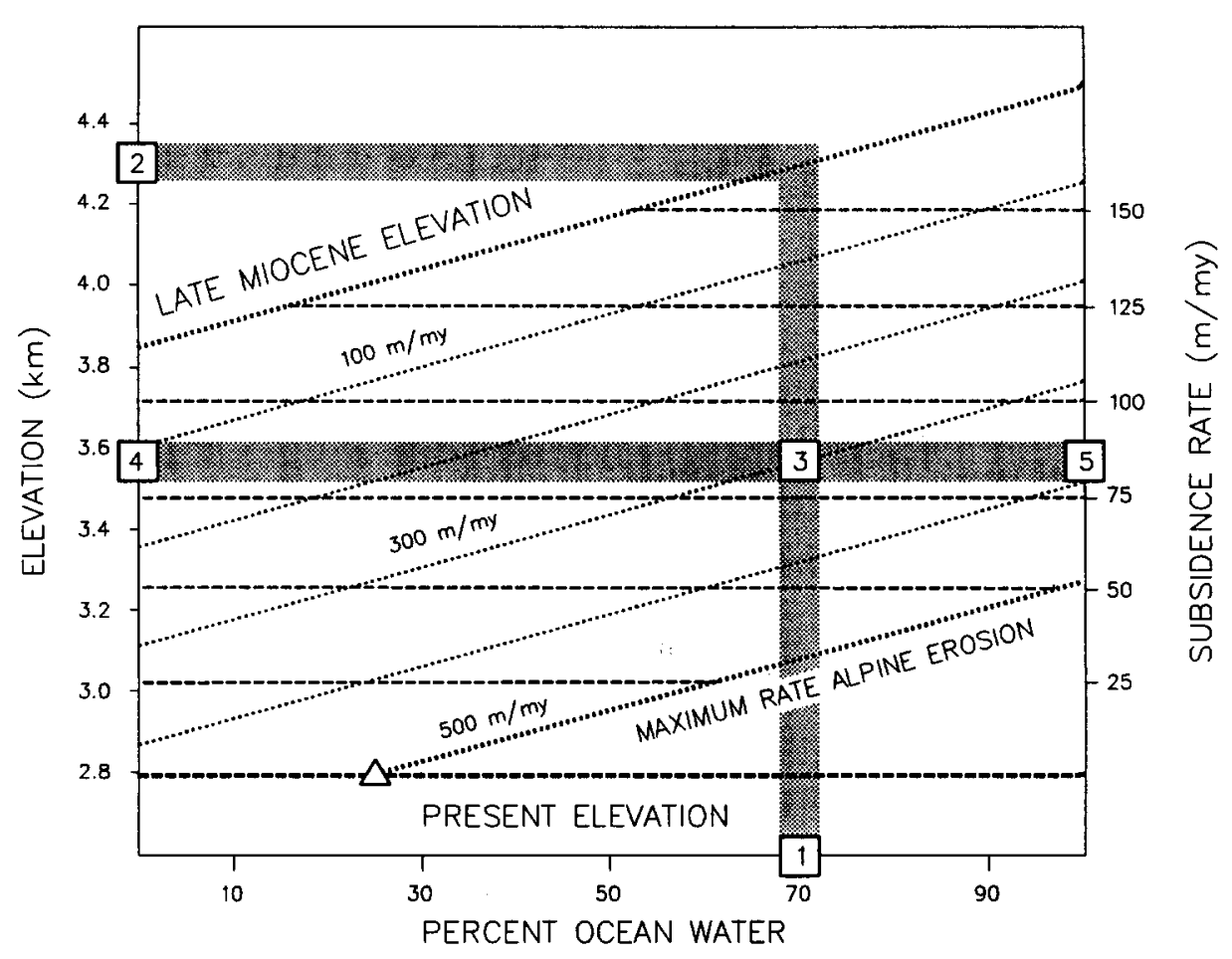

Fig. 6. Relations between source of meteoric water to Lake Camp Davis (regional lake versus global marine; horizontal axis) and the relative importance of erosion and subsidence in lowering catchment basin elevations. Upper dotted diagonal line is the estimated elevation of the Miocene Gros Ventre Mountains as a function of water source; present elevation of the Gros Ventre range $(2.8 \mathrm{~km})$ shown as the lower dashed horizontal line. Dotted lines parallel to the Miocene elevation are anticipated present elevations given various rates of erosion over the last $9.2 \mathrm{my}$. Intersection of maximum rates of erosion reported from modern alpine regions $(500 \mathrm{~m} / \mathrm{m} . \mathrm{y}$; ; lower dotted diagonal line) with present elevation (open triangle) indicates that no more than $25 \%$ of meteoric water could have been derived from global oceans if erosion was the only important process in the post-Miocene lowering of the Gros Ventre Range. Greater contributions of oceanic vapor require greater amounts of epirogenic subsidence to reach present elevations. If, for example, $70 \%$ of meteoric water was sourced from global oceans (1), mean catchment elevation would have been about $4.3 \mathrm{~km}(2)$, requiring some $1.5 \mathrm{~km}$ of post-Miocene lowering. If crustal thinning via erosion proceeded at $300 \mathrm{~m} / \mathrm{m} . \mathrm{y}$. (3), net elevation would be reduced to about $3.5 \mathrm{~km}(4)$. The remaining $0.8 \mathrm{~km}$ of lowering therefore requires a subsidence rate of some 84 m/m.y. (5).

elevation change indicated by limestone compositions. Greater amounts of ocean-derived water in meteoric precipitation require greater Miocene elevation of the Gros Ventre range (Fig. 5) and, as a result, greater amounts of inferred post-Miocene reduction in mountain elevation (Figs. 6 and 7).

\section{Conclusions}

Paleoelevation can play a significant role in determining both the isotopic composition of meteoric precipitation and the nature of regional climate in which precipitation occurs. In a context of interpreting the stable isotopic record of continental paleoclimate, however, reconstruction of catch- ment elevations is also strongly dependent on the relative importance of global versus regional sources of vapor for meteoric precipitation. In spite of our incomplete knowledge of the relative importance of these sources in ancient continental settings, a combination of data on rates of epirogenic subsidence, on erosional denudation, and on the isotopic composition of meteoric precipitation in modern settings allows for the construction of several limiting scenarios.

Isotopic compositions of lacustrine carbonate from the late Miocene Camp Davis Formation indicate that mean elevation of lake drainage catchment basins within the Gros Ventre Mountains were $0.5-1.2 \mathrm{~km}$ higher than at present; if 


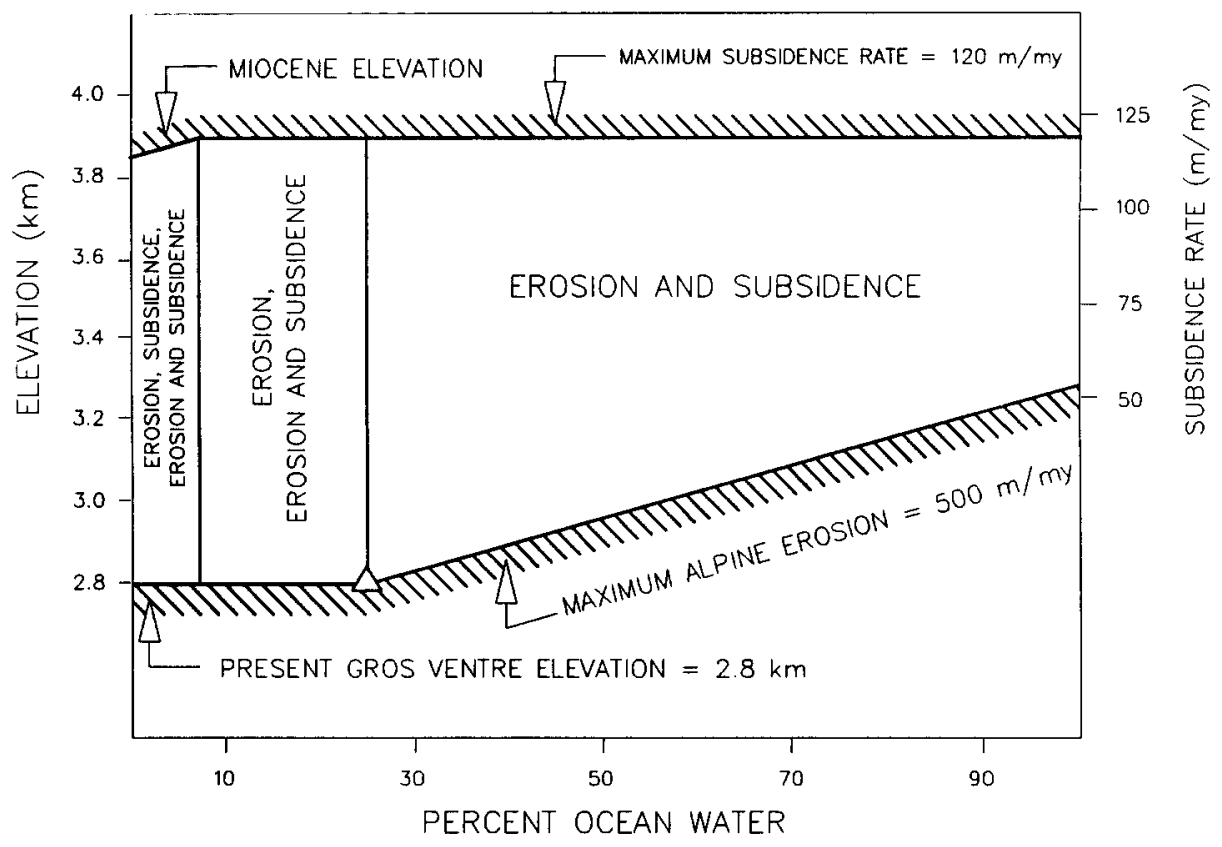

Fig. 7. Summary of the potential importance of erosion and/or subsidence as a function of water vapor mixing. Field boundaries from Fig. 6 were selected at the maximum elevation of Gros Ventre catchments (Miocene elevation), a maximum subsidence rate of $120 \mathrm{~m} / \mathrm{m} . y$. , a maximum erosion rate of $500 \mathrm{~m} / \mathrm{m} . \mathrm{y}$., and a present mean elevation of $2.8 \mathrm{~km}$. Depending on the relative contribution of global oceans versus regional lakes to Miocene meteoric water vapor (horizontal axis), post-Miocene lowering of the Gros Ventre range could reflect: (1) erosion, subsidence, or erosion plus subsidence; (2) erosion or erosion plus subsidence; or (3) erosion plus subsidence.

post-Miocene lowering of this range largely reflects surficial erosion within the southern Rocky Mountains, recycling of meteoric water through large lake systems to the west must have provided over $75 \%$ of the water vapor falling on these catchments. Conversely, if global oceans provided a volumetrically subequal source of vapor for late Miocene meteoric precipitation, and if this vapor was generally isotopically unaffected by continental recycling during transport, erosional lowering of this portion of the southern Rocky Mountains must also have been accompanied by tectonic subsidence on the order of some $1.1 \mathrm{~km}$ over the past 9.2 my. While elevation-erosion-subsidence relations cannot be uniquely resolved from available data, it is clear that not all post-Miocene lowering of Gros Ventre drainage catchments can be explained by subaerial erosion, and that some indeterminate yet important fraction of this lowering reflects post-Laramide epeirogenic subsidence within the Southern Rocky Mountains.

\section{Acknowledgements}

Isotopic investigation of the Camp Davis Formation was initiated in preparation for a field trip conducted during the American Geophysical Union Chapman Conference on Isotopic Indicators of Continental Paleoclimate held in Jackson, Wyoming in June of 1991. We thank Peter Swart and Judy McKenzie who organized this conference and many of the participants for their insightful assessment of preliminary data. Our colleagues at the University of Michigan, Linda Albertzart, David Dettman, Jim O'Neil, Bill Patterson, Brad Opdyke, and James Walker are also gratefully acknowledged for helpful discussion and encouragement during this investigation. Early drafts of the manuscript greatly benefited from substantial reviews by Kerry Kelts and William Hay. Research on ancient lacustrine carbonates at the University of Michigan is supported by the National Science Foundation, NSF grant EAR-90-19095. 


\section{References}

Abell, P.I. and Williams, M.A.J., 1989. Oxygen and carbon isotope ratios in gastropod shells as indicators of paleoenvironments in the Afar region of Ethiopia. Palaeogeogr., Palaeoclimatol., Palaeoecol., 74: 265-278.

Axelrod, D.I., 1964. The Miocene Trapper Creek flora of southern Idaho: Univ. Calif. Publ. Geol. Sci., 148 pp.

Barnosky, A.D. and Labar, W. J., 1989. Mid-Miocene (Barstovian) environmental and tectonic setting near Yellowstone Park, Wyoming and Montana. Geol. Soc. Am. Bull., 101: 1448-1456.

Baumgartner, A. and Reichel, E., 1975. The World Water Balance. Elsevier, New York, $179 \mathrm{pp}$.

Bein, A., 1986. Stable isotopes, iron and phosphorus in a sequence of lacustrine carbonates--paleolimnic implications. Chem. Geol., 59: 305-313.

Bellanca, A., Calvo, J.P., Censi, P., Elizaga, E. and Nere, R., 1989. Evolution of lacustrine diatomite carbonate cycles of Miocene age, southeastern Spain: petrology and isotope geochemistry. J. Sediment. Petrol., 59: 45-52.

Boyer, B.W., 1981. Tertiary lacustrine sediments from Sentinel Butte, North Dakota and the sedimentary record of ectogenic meromixis. J. Sediment. Petrol., 51: 429-440.

Clarke, S.P. and Jager, E., 1969. Denudation rate in the Alps from geochronologic and heat flow data. Am. J. Sci., 267: $1143-1160$.

Cole, M.R. and Armentrout, J.M., 1979. In: J.M. Armentrout, M.R. Cole and H. Terbest (Editors), Cenozoic Paleogeography of the Western United States. SEPM, Pac.Sect., Denver, pp. 1-335.

Couples, G. and Stearns, D.W., 1978. Analytical solutions applied to structures of the Rocky Mountains foreland on local and regional scales. Geol. Soc. Am. Mem., 151: 313-335.

Craig, H. and Gordon, L.I., 1965. Deuterium and oxygen-18 variations in the ocean and the marine atmosphere. In: $\mathrm{E}$. Tongiorgi (Editor), Stable Isotopes in Oceanographic Studies and Paleotemperatures. Lab. Geol. Nucl., Pisa, pp. 9-130.

Dansgaard, W., 1964. Stable isotopes in precipitation. Tellus, 16: 436-468.

Davis, R.L. and Wilkinson, B.H., 1983. Sedimentology and petrology of freshwater lacustrine carbonate: mid-Tertiary Camp Davis Formation, northwestern Wyoming. Contrib. Geol., 22: 45-55.

Dorr, J.A., Spearing, D.R. and Steidmann, J.R., 1977. Deformation and deposition between a foreland uplift and an impinging thrust belt: Holback Basin, Wyoming. Geol. Soc. Am. Spec. Pap., 177, p. 82.

Eicher, U., Siegenthaler, U. and Wegmuller, S., 1981. Pollen and oxygen isotope analyses on late- and post-glacial sediments of the Tourbiere de Chirens (Dauphine, France). Quat Res., 15: 160-170.

Eicher, U. and Siegenthaler, U., 1976. Palynological and oxygen isotope investigations on late-glacial sediment cores from Swiss lakes. Boreas, 5: 109-117.

England, P. and Molnar, P., 1990. Surface uplift, uplift of rocks, and exhumation of rocks. Geology, 18: 1173-1177.

Epstein, S., Buchsbaum, R., Lowenstam, H.A. and Urey, H.C.,
1953. Revised carbonate-water temperature scale. Geol. Soc Am. Bull., 63: 417-426.

Erslev, E.A., 1986. Basement balancing of Rocky Mountain foreland uplifts. Geology, 14: 259-262.

Evanoff, E., 1990. Early Oligocene paleovalleys in southern and central Wyoming: Evidence of high local relief on the late Eocene unconformity. Geology, 18: 443-446.

Evernden, J.F., Savagem, D.E., Curtis, G.H. and James, G.T., 1964. Potassium-Argon dates and the Cenozoic mammalian chronology of North America. Am. J. Sci., 262: 145-198.

Fritz, P. and Poplawski, S., $1974 .{ }^{18} \mathrm{O}$ and ${ }^{13} \mathrm{C}$ in the shells of freshwater molluses and their environments. Earth Planet. Sci. Lett., 24: 91-98.

Fritz, P., Anderson, T.W. and Lewis, C.F.M., 1975. LateQuaternary climatic trends and history of Lake Erie from stable isotope studies. Science, 190: 267-269.

Gilluly, J., 1949. The distribution of mountain building in geologic time. Geol. Soc. Am. Bull, 60: 561-590.

Gregory, K.M. and Chase, C.G., 1992. Tectonic significance of paleobotanically estimated climate and altitude of the late Eocene erosion surface. Geology, 20: 581-585.

Gregory, R.T., Douthitt, C.B., Duddy, I.R., Rich, P.V. and Rich, T.H., 1989. Oxygen isotopic composition of carbonate concretions from the Lower Cretaceous of Victoria, Australia: Implications for the evolution of meteoric waters on the Australian continent in a paleopolar environment. Earth Planet. Sci. Lett., 92: 27-42.

Hildebrand, R.T. and Newman, K.R., 1985. Miocene sedimentation in the Goose Creek Basin, south-central Idaho, Northeastern Nevada, and northwestern Utah. In: R.M. Flores and S.S. Kaplan (Editors), Cenozoic Paleogeography of west-central United States. SEPM, Rocky Mountain Sect., Denver, p. 55-70.

Hillaire-Marcel, C. and Casanova, J., 1987. Isotope hydrology and paleohydrology of the Magadi (Kenya)-Natron (Tanzania) basin during the Late Quaternary. Palaeogeogr., Palaeoclimatol., Palaeoecol., 58: 155-181.

IAEA, 1969-1990. International Atomic Energy Agency Tech. Rep. Ser., 1-9.

Irion, G. and Muller, G., 1968. Mineralogy, petrology and chemical composition of some calcareous tufa from the Schwäbische Alb, Germany. In: G. Muller and G.M. Friedman (Editors), Recent Developments in Carbonate Sedimentology in Central Europe. Springer, New York, pp. $157-171$.

Kelts, K. and Talbot, M.R., 1986. Evidence of environmental change from stable isotopic signals in lacustrine carbonates: the Quaternary record from Lake Bosumtwi, Ghana. In: H. Faure (Editor), INQUA Symp. Changements globaux en Afrique, Dakar, pp. 181-184.

Kelts, K. and Talbot, M.R., 1989. Lacustrine carbonates as geochemical archives of environmental change and bioticabiotic interactions. In: M.M. Tilzer and C. Serruya (Editors), Ecological Structure and Function in Large Lakes. Sci Technol. Publ., Madison, Wisc., pp. 290-317.

Leopold, E.B. and MacGinitie, H.D., 1972. Development and affinities of Tertiary Floras in the Rocky Mountains. In: A. Graham (Editor), Floristics and Palaeofloristics of Asia and Eastern N. America. Elsevier, Amsterdam, pp. 147-200.

Love, T.C., 1986. Geochemical correlation of Salt Lake- 
equivalent pyroclastic deposits in Idaho and Wyoming. Thesis. Univ. New Orleans, p. 114.

McKenzie, J., [985. Carbon isotopes and productivity in the lacustrine and marine environment. In: W. Stumm (Editor), Chemical Processes in Lakes. Wiley, New York, pp. 99-118.

McKenzie, J. and Eberli, G.P., 1987. Indications for abrupt Holocene climatic change: Late Holocene oxygen isotope stratigraphy of the Great Salt Lake, Utah. In: W.H. Berger and L.D. Labeyrie (Editors), Abrupt Climate Change. Reidel, Dordrecht, pp. 127-136.

Menard, H.W., 1961. Some rates of regional erosion. J. Geol., 69: 154-161

Menard, H.W., Smith, S.M. and Pratt, R.M., 1965. The Rhone deep-sea fan. In: W.F. Whittard and R. Bradshaw (Editors), Submarine Geology and Geophysics. Butterworths, London, pp. $271-285$

Murphy, D.H. and Wilkinson, B.H., 1980. Carbonate deposition and facies distribution in a central Michigan marl lake Sedimentology, 27: 123-135.

O’Neil, J.R., Clayton, R.N. and Mayeda, T.K., 1964. Oxygen isotope fractionation in divalent metal carbonates. J. Chem. Phys., 51: 5547-5558.

Riding, R., 1979. Origin and diagenesis of lacustrine algal bioherms at the margin of the Ries crater, Upper Miocene, southern Germany. Sedimentology, 26: 645-680.

Ritchie, E.L., 1981. Geochemical correlation of Tertiary volcanic ash, Idaho and Wyoming. Thesis. Univ. New Orleans, p. 60 .

Schmidt, D.L. and Friedman, I., 1974. Continental deposition of Antarctic tillite indicated by carbon and oxygen isotopes. U.S. Geol. Surv. J. Res., 2: 711-715.

Schoell, M., 1978. Stable isotope analyses on authigenic carbonates from Lake Van sediments and their possible bearing on the climate of the past 10,000 years. In: E.T. Degens and F. Kurtman (Editors), The Geology of Lake Van. M.T.A. Press, Ankara, pp. 92-97.

Schwarcz, H.P. and Eyles, N., 1992. Laurentide ice sheet extent inferred from stable isotopic composition $(\mathrm{O}, \mathrm{C})$ of ostracodes at Toronto, Canada. Quat. Res., 37: 243-261.

Shuster, M.W. and Steidtmann, J.R., 1988. Tectonic and sedimentary evolution of the northern Green River basin, western Wyoming. Geol. Soc. Am. Mem., 17I: 515-529.

Smith, G.I., Friedman, I., Klieforth, H. and Hardcastle, K.,
1979. Areal distribution of deuterium in eastern California precipitation, 1968-1969. J. Appl. Meteorol., 18: 172-188.

Smithson, S.B., Brewer, J., Kaufman, S, Oliver, J. and Hurich, C., 1978. Nature of the Wind River thrust, Wyoming, from COCORP deep-reflection data and from gravity data. Geology, 6: 648-652.

Steidtmann, J.R., Middleton, L.T. and Shuster, M.W., 1989. Post-Laramide (Oligocene) uplift in the Wind River Range, Wyoming. Geology, 17: 38-41.

Steidtmann, J.R. and Middleton, L.T., 1991. Fault chronology and uplift history of the southern Wind River Range, Wyoming: Implications for Laramide and post-Laramide deformation in the Rocky Mountain foreland. Geol. Soc. Am. Bull., 103: 472-485.

Stiller, M. and Kaufman, A., 1985. Paleoclimatic trends revealed by the isotopic composition of carbonates in Lake Kinneret. Z. Gletscherkd. Glazialgeol., 21: 79-87.

Straccia, F.G., Wilkinson, B.H. and Smith, G.R., 1990. Miocene lacustrine algal reefs - southwestern Snake River Plain, Idaho. Sediment. Geol., 67: 7-28.

Stuiver, M., 1970. Oxygen and carbon isotope ratios of freshwater carbonates as climatic indicators. J. Geophys. Res., 75: 5247-5257.

Suchecki, R.K., Hubert, J.F. and Birney De Wet, C.C., 1988. Isotopic imprint of climate and hydrogeochemistry on terrestrial strata of the Triassic-Jurassic Hartford and Fundy rift basins. J. Sediment. Petrol., 58: 801-811.

Swrydczuk, K., Wilkinson, B.H. and Smith, G.R., 1979. The Pliocene Glenns Ferry oolite: Lake-margin carbonate deposition in the southwestern Snake River plain. J. Sediment. Petrol., 49: 995-1004.

Talbot, M.R., 1990. A review of the paleohydrological interpretaion of carbon and oxygen isotope ratios in primary lacustrine carbonates. Chem. Geol., 80: 261-279.

Treese, K.L. and Wilkinson, B.H., 1982. Peat-marl deposition in a Holocene paludal-lacustrine basin-Sucker Lake, Michigan. Sedimentology, 29: 375-390.

Van der Voo, R., 1989. Paleomagnetism of North America; the craton, its margins and the Appalachian Belt. In: L.C. Pakiser and W.D. Mooney (Editors), Geophysical framework of the continental United States. Geol. Soc. Am. Mem., 172: 447-470.

Wetzel, R.G., 1975. Limnology. Saunders, Philadelphia, PA, p. 743 . 